\begin{tabular}{|l|l|}
\hline DOl:10.17951/we.2018.4.1.121. & Wschód Europy • Восток Европы • East of Europe vol 4, 1 / 2018 \\
\hline
\end{tabular}

Robert Rajczyk

The University of Silesia in Katowice

\title{
Media system in the Republic of Moldova
}

\section{Introduction}

The Republic of Moldova is a small country situated between Romania and Ukraine. In the political tradition, contemporary Moldova alludes to the historic heritage of the Principality of Moldova, although this seems to be a huge simplification due to the diversity of the territorial range and the lack of the state and legal continuity between the then principality and Moldova of this day. In 1812,eastern part of the Principality of Moldova, as a result of peace treaty between the Russian Empire and the Ottoman Empire became the part of Russia. The areas situated between The Prut and Dniester River started to be called Bessarabia Governorate (Bessarabia) - the name probable coming from the medieval ruler of Wallachia. The Principality of Moldova, reduced to western part, allied with the Principality of Wallachia by a personal union in 1859 to finally form the United Romanian Principalities. Thus, modern Moldova is not only the sovereign Republic of Moldova but also the name of the historic and geographic land in Romania. On March 27 $7^{\text {th }}$, 1918, the local parliament called The Council of the State adopted the resolution on the basis of which Bessarabia became the part of the Kingdom of Romania. In 1924, the Soviet Union, which made the territorial claims towards Romania, formed the Moldovan Autonomous Socialist Soviet Republic being the component of The Ukrainian Socialist Soviet republic, on the areas which were not the part of the Principality of Moldova - to the east from the bordering Dniester River. As Bartłomiej Zdaniuk put it: it was to be "the political bulwark of the Russian power preparing the ground for the future takeover of Bessarabia"1. In 1940, the USSR implementing the resolutions of the Ribbentrop - Molotov Pact annexed Bessarabia. Its central part was joined to the Moldovan Autonomous Socialist Soviet Republic situated on the left bank of the Dniester River and transformed into the Moldovan Socialist Soviet Republic. Northern and southern fragments of Bessarabia were included in the Ukrainian Socialist Soviet Republic. Consequently, in the political and historic context

1 B. Zdaniuk, Konsolidacja państwa w Republice Mołdawii, Warszawa 2016, p. 96. 
and the state tradition, the today Moldova is historically rooted not in the Principality of Moldova but in the heritage of Bessarabia Governorate, and above all from the Soviet Moldova.

The Republic of Moldova proclaimed its independence on August $27^{\text {th }}, 1991$. While analyzing the twenty-year-old period of its sovereign existence, it is important to point out to the constantly lasting process of transformation and consolidation in the dimension of ethnopolitical community, territory and political system. It should be emphasized that de iure Moldova is a uniform state but on the area located on the left bank of the Dniester River, since 1992 there has been functioning de facto para-state organism that is not controlled by the authorities in Chisinau. Uncrecognized as a sovereign subject from the point of view of the international law, the so-called Transnistrian Republic of Moldova has its own public institutions and political and economic system, which largely depends on the economic aid of the Russian Federation. It also possesses its own media system. The sub-system of the Moldovan media system functions in the area of the Autonomous Territory of Gagauzia with the population of the ethnogenesis close to the Turkish one but belonging to the Orthodox Church and speaking Russian in their everyday communication although they have their own language - Gagauzian, which is the subject of legal protection.

In the Republic of Moldova, the public institutions typical for a sovereign country were established, however, their functioning is far from being efficient. The Moldovan state, in some aspects, is not able to guarantee the implementation of public tasks to its citizens. As Kamil Całus argues, the Republic of Moldova still lacks the national idea, the political system has the oligarchic character and the legal system is weak and inefficient $^{2}$. In the formal and legal aspect, the Moldovan system of government adopted the parliamentary and cabinet model, in which the constitution guarantees respecting of the citizen rights and freedoms including freedom of speech and expression. These two freedoms as well as the right to information and statutory guarantee of access to it are of crucial importance from the point of view of this study.

\section{Formal and legal aspect}

While analyzing the problems connected with the functioning of the media system in its formal and legal dimension, it is important to indicate the regulation of this area in as many as fifteen legal acts of various rank, beginning with the Constitution and ending at the internal regulations of The Supreme Council of the Judiciary concerning the availability of public information and making it available to journalists.

Considering the formal and legal problems sensu largo, the constitutional guarantees of freedom of speech, press and expression should be emphasized. The citizens have these rights and freedoms in public but at the same time they cannot infringe the rights of the third people including their dignity, encourage quarrels on the religious

2 K. Całus, Państwo niedokończone. 25 lat mołdawskiej niepodległości, Warszawa 2016, p. 5-9. 
and ethnic background, incite to hatred and territorial separatism ${ }^{3}$. Calling for war and dissemination of false information are punishable by financial penalty or deprivation of freedom from 3 to 7 years and the ban on occupying of certain positions in the mass media for the period of five years ${ }^{4}$.

The normative act guaranteeing the functioning of freedom of speech in practice is the act on freedom of expression which embraces freedom of searching, receiving and spreading of facts and ideas. This also involves the right to criticize the activity of the state organs and people holding public functions. The act excludes submission of claims for defamation and special legal protection of the legislative and executive bodies. It is worth noting that people holding public positions may be the subject of criticism and their activities are the subject of verification by the mass media ${ }^{5}$. However, it should be emphasized that the information about private and family life of people occupying public posts may be disclosed only in the situation when it is connected with the public interest with the reservation that the dissemination of that kind of knowledge will not lead to unjustified harm of the third parties ${ }^{6}$. Freedom of speech may be restricted in exclusively statutory way and in cases necessary for the country's security, public order, protection of health and public morality and guaranteeing of impartiality of the judicial power ${ }^{7}$. However, this restriction must be proportional to the threat and must maintain the balance between freedom of speech and the right of the society to information.

Problems of the formal and legal specificity of the Moldovan media market sensu stricto will cover the regulations relating to the right to information and the access to information. The citizens enjoy the right to information but it cannot pose any threat to the citizens' and national security. In Moldova, the right to complete, objective and reliable information, the right to free expression of views and the right to free dissemination of information via radio and television are guaranteed by the law ${ }^{8}$. The mass media are obliged to pass true information and are not submitted to censorship', although in the situation of endangered country's security, territorial integrity, public security or state secret - such measures may be undertaken but only on the basis of the decision of the

3 Constituția 29 iulie 1994, Monitorul Oficial al R.Moldova nr.1 din 12.08.1994, art. 32.

4 Lege Codul penal al Republicii Moldova nr. 985-XV din 18.04.2002 Republicat: Monitorul Oficial al R.Moldova nr. 72-74/195 din 14.04.2009 Monitorul Oficial al R.Moldova no.128-129/1012 din 13.09.2002, art. 140 .

5 Lege cu privire la libertatea de exprimare nr. 64 din 23.04.2010 Monitorul Oficial no.117-118/355 din 09.07.2010, art. 5 .

6 Lege cu privire la libertatea de exprimare nr. 64 din 23.04.2010 Monitorul Oficial no.117-118/355 din 09.07.2010, art. 6, art. 9, art. 11 item 2.

7 Lege cu privire la libertatea de exprimare nr. 64 din 23.04.2010 Monitorul Oficial no.117-118/355 din 09.07.2010, art. 5 .

8 Lege Codul audiovizualului al Republicii Moldova no. 260-XVI din 27.07.2006 Monitorul Oficial no. 131-133/679 din 18.08.2006, art. 10 item 1.

9 Constituția 29 iulie 1994, Monitorul Oficial al R.Moldova nr.1 din 12.08.1994, art. 34. 
independent court ${ }^{10}$. Freedom of speech is guaranteed to the media by, among others, the above mentioned act. Prohibiting or preventing of publishing of information constituting the public interest is not allowed. The mass media must inform the public opinion of all the matters referring to the public interest including the use of journalistic provocation ${ }^{11}$.

Broadcasters in the Republic of Moldova have freedom of shaping of the program content but at the same time are obliged to show the diversity of views. Any interference of the public authorities or other subjects with the program content is forbidden. Broadcasters must ensure objectivity in information programs in this way also encouraging freedom of formulating of views by receivers ${ }^{12}$. In order to achieve this, the public authorities are obliged to guarantee the protection of journalists against pressure and threats that could impede their work but that cannot be connected with the restriction of their freedom to exercise professional activities. Consequently, exerting pressure or intimidating of journalists is penalized ${ }^{13}$.

\section{Institutional aspect}

The basic legal act regulating the operation of the radio and television market is the Audio-visual Code. It defines the areas of the media activity and legitimizes advertising, telemarketing and sponsorship. The act also contains the guarantees of journalistic independence, protection of information sources, right to information, freedom of expression and dissemination of information. The regulations also specify the broadcasters' necessity to represent political pluralism and journalistic reliability and protection of human dignity and language, cultural and national heritage, as well as of protection of children against the negative influence of the broadcast content.

The act establishes the Coordination Council of Audio-visual Matters as the state regulatory body of the media market. An interesting thing is that the council is not the constitutional organ. The Moldovan constitution only indicates the possibility to establish specialized organs of the central state administration ${ }^{14}$. In practice, that means that the change of the act requires ordinary majority of votes, whereas the amendment of the Constitution would require the two-thirds of the deputies' votes (67 out of 101).

Nominally, the Coordination Council is an independent organ of the public administration which consists of nine members chosen by the parliament by the majority of three-fifths of the deputies' votes. This practically means that each of the candidates to the Council, apart from meeting formal requirements such as higher education, the

10 Lege cu privire la libertatea de exprimare nr. 64 din 23.04.2010 Monitorul Oficial no.117-118/355 din 09.07.2010, art. 6 item 3.

11 Lege cu privire la libertatea de exprimare nr. 64 din 23.04.2010 Monitorul Oficial no.117-118/355 din 09.07.2010, art. 4 .

12 Lege Codul audiovizualului al Republicii Moldova nr. 260-XVI din 27.07.2006 Monitorul Oficial no. $131-133 / 679$ din 18.08 .2006 , art. 8 and art. 8 item 5 .

13 Lege cu privire la libertatea de exprimare nr. 64 din 23.04.2010 Monitorul Oficial no.117-118/355 din 09.07.2010, art. 15 .

14 Constituţia 29 iulie 1994, Monitorul Oficial al R.Moldova no.1 din 12.08.1994, art. 107 item 2. 
age of 25 and minimum 5-year-experience of work in the audio-visual sector, communication technologies, law, finances, accounting or management, must be supported by 61 out of 101 MPs. It is worth noting that by March 2006,the president of Moldova was chosen by the same majority of votes ${ }^{15}$. The Coordination Council announces the contest and presents to the parliament candidates for the members of another important council in the Moldovan media system - the Supervisory Board of the public broadcaster - Teleradio Moldova, the company which focuses the public TV and ra$\mathrm{dio}^{16}$. Nine members are chosen for the four-year office by the majority of three-fifths of votes. The company's organs chosen by the Supervisory Board are the president of Teleradio-Moldova Company and directors of the public radio and television. They are prominent persons from the world of culture and art but also journalists, lawyers, financiers, representatives of non-governmental organizations, Public Relations, media, education and international relationships. They are chosen in the course of the contest procedure conducted by the Supervisory Board. It should be stressed out here that due to the fact that it is necessary to obtain the majority of three-fifths of votes to elect the members of both the Coordination Council and the Supervisory Board of Teleradio-Moldova Company, this solution requires the political consensus because none of political parties has the majority of 61 votes of mandated 101 in the parliament.

The audio-visual Code also provides for the operation of the regional public broadcasters on the Moldovan media market. It mainly concerns "Teleradio-Gagauzia" responsible for the operation of the public media in the area of the Autonomous Territory of Gagauzia ${ }^{17}$. This autonomy is also in charge of the process of the local law making. Its legislative body called the National Assembly, adopted the resolution regulating the concession procedure in the area of the autonomy and functioning of the regional media market. That legal act enables the regional parliament to choose the Supervisory Board of Teleradio-Gagauzia Company - the regional public broadcaster. The amendment of this act of local law confers the competence of managing of regional radio and television to the Executive Committee under the leadership of baszkan - the governor of Gagauzia chosen by the residents ${ }^{18}$. The concession process is a significant element

15 K. Całus, Mołdawia: Sąd Konstytucyjny zmienia tryb wyboru prezydenta, https://www.osw.waw.pl/ $\mathrm{pl} /$ publikacje/analizy/2016-03-09/moldawia-sad-konstytucyjny-zmienia-tryb-wyboru-prezydenta, inf. of 09.01.2017.

16 Respectively: TV Moldova 1 and 3 radio stations: Radio Moldova Actualitati, Radio Moldova Tineret and Radio Moldova Muzical.

17 Lege Codul audiovizualului al Republicii Moldova no.. 260-XVI din 27.07.2006 Monitorul Oficial no.131-133/679 din 18.08.2006, art. 65. It is worth paying attention to the fact that the act provides the operation of the regional public broadcaster, also in the territories situated in on the left bank of the Dniester River. This type of wording was already used in the Moldovan Constitution and it is, from the formal and legal point of view, to guarantee the territorial integrity of the Republic of Moldova which contains the para-state of the Moldovan Republic of Transnistria, not recognized by the international community.

18 More on the constitutional system of Moldova and the legal system of The Autonomous Territory of Gagauzia see: R. Rajczyk, System konstytucyjny Mołdawii, Warszawa 2012. 
of shaping of the media market and influencing its receivers, especially that it is the executive organ that decides about it. This also means potential competence and legal disputes referring to the operational responsibility of the Coordination Council. The Council has the limited possibilities of fulfilling its statutory tasks in the light of the above presented legal solutions in force on the Autonomous Territory of Gagauzia.

\section{Mass media in Moldova}

According to the opinion polls of November 2015, 63\% of respondents consider TV as the main source of information. The second comes the Internet with the index of $24 \%{ }^{19}$. Television prevails as the source of information mainly in the rural and non-urbanised areas due to the technical problems connected with access to the Internet network and financial barrier. The data obtained from the opinion polls suggest that in 2011 for only $2 \%$ of respondents the press was the most important source of information about the word, whereas the trust in the press was declared by only $3 \%$ of the surveyed individuals. It is worth emphasizing that the printed media in Moldova are published mainly in the Moldovan language (similar to Romanian) and in Russian. There are two significant elements that distinguish the Moldovan media market - strong political influence exerted on the media ${ }^{20}$ and the share of the closed distribution via the Moldovan postal operator - the Moldovan Post Office ${ }^{21}$. According to the data from the National Statistical Bureau of the Republic of Moldova, the closed distribution and sale in post offices in 2015 amounted to 15,9 million copies ${ }^{22}$. It should be borne in mind that the population of Moldova (without Transistria) is 3,5 million.

Political influence should be understood as far reaching instrumentalization manifesting in political provenance of the owners. This concerns the owners associated with concrete political groups such as Vlad Plahotniuc (the leader of the Democratic Country) or favoring of one specific political option such as for example Jurnal TV, the opposition focused around the ex-candidate for the office of president, Maja Sandu. The regulations that are in force in Moldova order the openness and transparency of the ownership structure of mass media. At the beginnings of the independent existence of Moldova as a state, the efforts of the restoration of ideological and political function of the press could be observed ${ }^{23}$.

19 Press Freedom Report, Independent Journalism Center, Chisinau 2015, http://media-azi.md/sites/default/files/raportul_privind_situatia_presei_in_engleza_final_spre_publicare.PDF, inf. of 12.01.2017.

20 By party-based system one should understand fostering of individual actors of the political life by the selective choice of the published content. It particularly refers to the TV stations due to their social influence and technical scope.

${ }_{21}^{21}$ Media landscapes of Eastern Partnership countries, Yerevan Press Club, Yerevan 2011, p. 80-81.

22 http://www.statistica.md/pageview.php?l=ro\&idc=263\&id=2209, inf. of 15.01.2017.

23 A. Puju, Media masowe w przestrzeni społeczno-politycznej współczesnej Mołdowy, [in:] Mało znane systemy medialne, Sosnowiec 2007, p. 45. 
The Internet, mentioned as the second source of information is used by nearly $40 \%$ of respondents every day or several times a week. $12 \%$ out of 1.3 million Moldovans declaring to be the Internet users treat this medium as the main source of information. Furthermore, the trust in this medium oscillates around the same percentage value ${ }^{24}$. The results from 2016 show the increase of the Internet users of about $30 \%$ over the period of the last five years ${ }^{25}$. The most popular Internet portals are: point.md, protv. md and unimedia. $\mathrm{md}^{26}$.

\subsection{Radio and television market}

According to the state of January 1st, 2016, the Coordination Council in Moldova granted the total of 207 concessions to broadcast radio and television programs and their re-transmissions. In the latter case, it mainly involves the re-transmission of programs in Russian and those coming from the Russian broadcasters emitting their program offer from outside of the area of the Republic of Moldova and the distribution of the radio and television signal via the cable way ${ }^{27}$.

Tabela 1. Radio and TV concessions in the Republic of Moldova.

\begin{tabular}{l|c|c|c}
\hline \multicolumn{1}{c|}{2015} & terrestial & $\begin{array}{c}\text { Satellite, including } \\
\text { terrestial distribution }\end{array}$ & Cable \\
\hline Television & 32 & $11, \mathrm{w}$ tym 4 & 31 \\
\hline Radio & 55 & 1 & 1 \\
\hline & cable & Terrestial digital TV & GSM \\
\hline Local operators & 73 & 2 & 1 \\
\hline
\end{tabular}

Source: own elaboration on thebasis of data from Raport privind activitatea CCC in anul 2015, p. 16, http://www.cca.md/files/RAPORT\%20CCA\%202015.pdf, inf. of 12.01.2017.

This means the operation on the electronic media market of 74 TV broadcasters and 57 radio ones $^{28}$. According to the data obtained from the Independent Journalism Center, the radio and television market in Moldova in terms of the capital is dominated by the leader of the currently rulling Democratic Party, Vlad Plahotniuc, who owns four nationwide TV stations (Publika TV, Prime, Canal 2, Canal 3) and three radio stations of the same range (Publika FM, Muz FM, Maestro FM), which in total amounts

${ }^{24}$ Ibidem, p. 82. According to the data obtained from the CIA World Factbook of 2014, in Moldovia there are $1.6 \mathrm{mln}$ of the registered Internet users.

$25 \mathrm{http} / / / \mathrm{www}$.internetlivestats.com/internet-users/moldova/.

26 Dane Gemius 2015, cit: Media sustainability index 2016, IREX, Waszyngton, 2016, p. 2.

27 Cable channels include: RTR-Moldova, Jurnal TV, PRO TV, Realitatea TV, Euro TV, Alt TV and N4.

28 Similar data are given by the National Statistical Bureau, which in 2015 reported the operation of 72 TV stations and 52 radio stations - comp. Media sustainability index 2016, IREX, Waszyngton 2016, p. 2. 
to about $60-70 \%$ of shares in the ${ }^{29}$. Television is the main tool of information influence on receivers as it constitutes the first source of information for them. Another characteristic feature of the Moldovan radio and television market is considerable share of the Russian-speaking TV stations which emit the local information content only in a slight degree. The exception is NTV Moldova, which declares 50\% content of local issues in its program offer ${ }^{30}$. It should be mentioned that Russian, apart from Moldovian, is commonly used in the inter-ethnical communication in the Republic of Moldova, and in some areas, for example near Bielce in the north of the country or in Gagauzia and Tarakla is the prevailing language of communication. The fact should be emphasized that the program content offered by the TV broadcasters from the Russian Federation promotes and presents the Russian point of view about the world at the same time strongly affecting the Moldovan viewer. According to the data of December 2016 obtained by the research center of the AGB Nielsen Media Research, the most popular TV stations with the audience in Moldova are: Prime TV, Canal 2, RTR Moldova and Moldova 1 (public) ${ }^{31}$. As far as the radio market is concerned, the results obtained by the Institutul de Politice suggest that the greatest number of listeners in 2014 had the private Radio Noroc, public Radio Moldova and private Russkoe Radio. The data of the AGB Nielsen Media Research OF 2013 mentioned Hit FM, Russkoe Radio and Radio Noroc as the most popular ones ${ }^{32}$.

While interpreting the above data, it should be noted that the Moldavian information space is submitted to the political and business groups and the program line depends on the interests of the owners of mass media ${ }^{33}$.

\subsection{Internet market}

According to the data from the catalogue of the Internet websites, in the category of „"news, mass media" there are 449 subjects registered in the Republic of Moldova which provide the information from these areas. They are independent Internet portals and websites of the editorial offices of the press, radio and television. Among them there are 50 radio broadcasters, $71 \mathrm{TV}$ providers, 38 information agencies, 54 magazines and newspapers and 148 Internet blogs. The separate sub-category constitutes 45 current

29 Press Freedom Report, Independent Journalism Center, Chisinau 2015, http://media-azi.md/sites/default/files/raportul_privind_situatia_presei_in_engleza_final_spre_publicare.PDF, inf. of 12.01.2017.

30 R. Olchowik, W 2016 r. startuje NTV Mołdawia, http://satkurier.pl/news/122954/w-2016r-startuje-ntv-moldawia.html oraz ntv.md, inf. of 15.01.2017.

31 Обзор телевизионной аудитории за декабрь 2016 года, TV MR MLD December 2016, http:// www.agb.md, inf. of 15.01.2017.

32 Media sustainability index 2016, IREX, Waszyngton 2016, p. 2.

33 The example of the political and business influence on the TV market is the establishment of the network of TV channels broadcast via the cable TV. Shifting of competitive programs to further positions influences their viewing. The example is TV7, whose owner was linked to the political and business opponent of Vlad Plahotniuc - Chiril Lucinschy, the son of ex-president Petru Lucinschy. See more: K. Całus, Państwo niedokończone. 25 lat mołdawskiej niepodległości, Prace OSW, no. 59, Ośrodek Studiów Wschodnich, Warszawa 2016, p. 40-42. 
affairs portals and 7 websites of the journalistic organizations ${ }^{34}$. It is essential to emphasize that the number of the websites of TV broadcasters is the same as the number of the granted TV and radio concessions. This may imply that firstly, the Moldovan market is quite stable and secondly, it has the growing potential ${ }^{35}$.

\subsection{The press and agency market}

According to the data obtained by the National Statistical Bureau of 2015, in Moldova, there are 171 newspapers and 258 magazines. Among them,the greatest ranges of readership have the following titles: "Komsomolskaia Pravda" (37,802), „Argumenti i Facti” (14,000), „Makler” (11,331), „Antenna” (11,268), „Unghiul” (10,000), „Timpul de dimineață” $(6,488)$, „Ekonomiceskoe Obozrenie” (5,651), „Panorama” $(3,300)^{36}$. The most popular magazines are: "Rabotai \& Otdahai” $(8,000)$, „Aquarelle" $(3,500)$, „Business Klass” $(2,500)$ from Bielce ${ }^{37}$. The press agencies functioning on the Moldovan media market involve: the state-owned Moldpress and private entrepreneurships. Spośród nich na szczególną uwagę zasługuje Novosti-Moldova deserves the particular attention. It was established in 2003 on the basis of partnership cooperation with the Russian information agency RIA Novosti. It currently offers the content belonging to the Russian broadcasting group Russia Siegodnia - Sputnik agency ${ }^{38}$.

\section{Mass media in Transnistria}

The para-state of the Transnistrian Republic of Moldova is characterized by the endemic media system. The fact should be stressed out that the economy in this region is dominated by the political and business group focused around Sheriff corporation. Thus, the Transnistrian press sensu largo may be divided into the private, being largely the property of the holding and periodicals being covered by the ownership control of local and central organs of the para-state's authorities.

The so-called public media involve these which are broadcast by the National Transnistrian Radio and Television Company (Russian: channel one Приднестровская Государственная Телерадиокомпания): “1 Transnistrian” (original name: Первый Приднестроский), radio station Radio 1 and information agency Novosti (Russian: Новости Приднестровья). It should be emphasized that only the official information agency of the Transnistrian Republic of Moldova runs the service in English ${ }^{39}$. The remaining two channels mentioned above offer the content in Russian, in spite of the

${ }^{34} \mathrm{http} / / / \mathrm{www}$. top20.md/stiri-massmedia, inf. of 15.01.2017.

35 The Moldovan Association of Adverising Agencies estimates the value of the Moldovan media market in the division into the following segments: $\mathrm{tv}$ - about $14.5 \mathrm{mln}$ euro, radio - 600 thousand., internet $-2.7 \mathrm{mln}$ and press $-2 \mathrm{mln}$, inf. from http://www.aapm.md/rom.html, inf. of 16.02.2017.

36 Data expressed in the number of copies. Original titles were saved, from: Media sustainability index 2016, IREX, Waszyngton 2016, p. 2.

37 Ibid.

38 Por. http://www.newsmoldova.md/, inf. of 15.01. 2017.

39 https://novostipmr.com/en. 
fact that the official language of the para-state is Ukrainian and Moldovan using the Cyrillic alphabet. The example of the media provided by the local organs of the authority is the newspaper established by the state administration of the district of Rybnica and the local council of people's deputies ${ }^{40}$, or "Novoie Vremea" published by the local administration in Bendery - the second largest city of Transnistria. The authorities of Dubossary issue their own periodical - "Zarea Pridnestrovie" and those of Grigoriopo - "Druzhba". Among the private media projects, special attention should be paid to the Internet initiatives such as dniester.ru or Internet TV dnestr.tv dealing with the analysis of the social and economic situation in the region. Within the scope of operation of private mass media, the activity of the information agency Vesti PMR is worth noticing ${ }^{41}$. It is situated on the media market as the broadcaster of local information also including the editorial project of agency website, divided in the news from all regions (a unit of the administrative and territorial division in Transnistria).

According to the information of the already cited report on the freedom of press issued by the Independent Center of Journalism of 2015, in Transnistria there were 49 editorial offices of newspapers and 8 magazines and information bulletins such as "Dnestrovskaya prawda" registered. Although periodical is positioned as a newspaper, due to its volume - four columns of A3 format, it may be regarded as a type of information bulletin ${ }^{42}$. In relation to the TV market, TSV channel should be mentioned belonging to Sheriff Holding politically linked to the organs of separatist authority of Transnistria. Also previously mentioned Internet TV Dnestr TV controlled by Grigori Volovov, owner of the radio station Novaya Volna is also a private property ${ }^{43}$. Benerskoe Televidenie which has been broadcasting for twenty years in Bendery is also a significant player on the TV market ${ }^{44}$.

\section{Mass media on the Autonomous Territory of Gagauzia}

According to Mihail Sirkeli, apart from the nationwide Moldovan broadcasters, there are four local TV stations on the autonomous territory, including public TV Gagauzia. The remaining three broadcasters emit their programs in the administrative units focused around the main Gagauzian urban centers: Komrat and Czadyr-Łunga. TV market is supplemented by the two cable TV operators offering the program of three

40 http://r-novosti.idknet.com/.

${ }^{41} \mathrm{http}: / /$ vestipmr.info.

42 http://tiraspol.tripod.com/.

43 According to the data obtained from the Moldovan Independent Center of Journalism, on the territory of the Transnistria there are 12 radio stations. See more on https://www.rise.md/english/ underground-deals-media-sheriffs-from-transnistria/, inf. of 15.02.17.

44 Comp. БЕНДЕРСКОЕ ТЕЛЕВИДЕНИЕ ОТМЕЧАЕТ 18-ЛЕТИЕ С НАЧАЛА ВЕЩАНИЯ, http:// bendery-ga.org/2952-benderskoe-televidenie-otmechaet-18-letie-s-nachala-veschaniya.html, inf. of 15.02.17. 
TV stations ${ }^{45}$. When it comes to the radio market, the technical range of three commercial broadcasters and one regional of the public status covers the whole Autonomous Territory of Gagauzia. Among the periodicals, M. Sirkeli mentions: „Vesti Gagauzii”, "Znamea” and „Edinaya Gagauzia” produced by the autonomy's authorities. Citing the author it should be emphasized that the above mentioned Gagauzian mass media focus exclusively on the information and current affairs activity. The latter being in fact limited to literally few programs such as political talk show. As Sirkeli notices there are no materials resulting from the journalistic investigation or documentaries. The lacks are supplemented by retransmission of foreign productions, mainly in Russian, which is understandable because the Gagauzians use this language in their everyday public communication. At this stage the attention should be paid to the fact that the part of the journalistic materials is also produced in the Gagauzian language, but in terms of quantitative aspect, they are rather trace figures ${ }^{46}$.

\section{Summary}

The main problems of the Moldovan media system are connected with the level of development of the political system. It is hard to call it the stable one, especially in the context of problems associated with the election of the president or questioning by the Constitutional Court of the method of election of the head of the state ${ }^{47}$. The ongoing process of oligarchization of economy also finds its reflection in the media market. Businesspeople who are crucial players in the Moldovan economy are associated with the concrete political groups. These sympathies manifest mainly in the selectivity of broadcast and presented program content and promoting of specific political options competing with each other on the political scene. It is of huge significance especially in the connection with the fact that television is one of the key sources of information about the political and social situation for the population of Moldova. The local media system is thus characterized by party-based approach (understood as promoting of specific political options) and monopolization (the example is prevalence of people politically linked to the most prominent oligarch - Vlad Plahotniuc in the authorities of the public media). Other problems connected with the Moldovan media market is the lack of diversity of own productions such as educational programs and documentaries as well as the program offer for the Russian-speaking part of the Moldovan population.

${ }_{45}$ M. Sirkeli, The ATU Gagauzia informational space and its influence on the moods of the public in the region [in:] Oazu Nantoi, Vasile Cantarji, Igor Botan, Anatol Gremalschi, Mihail Sirkeli, Moldova between East and West: views from Gagauzia and Taraclia, Chisinau 2002, http://www.ipp.md/ public/files/Studiu_en.pdf inf. of 15.02.17, p. 107.

46 Ibid., p. 108.

47 The brightest example is the case with the ex-president Vlad Filat, arrested for the bank affair involving withdrawing of milliard dollars from the banking system. Filat was the greatest business and politicalopponent of the most prominent Moldovan oligarch Vlad Plachotniuc, who, as the leader of one of coalition group- The Democratic Party, actually steers the course of politicalprocesses and the current management of the country through subordinated politicians. 
M. Sirkeli also emphasizes that Moldovan TV channels hardly ever offer the foreign service and do not have any foreign correspondent ${ }^{48}$.

The Gagauzian media sub-system is, on the other hand, characterized by the availability of the program offer of the nationwide broadcasters, but the most important are those program contents which are prepared in the Russian language due to its common use in everyday communication and religious life but also to the political sympathies as the Gagauzians are traditionally very pro-Russian and foster the Transnistrian separatists.

The media system in Transnistria operates independently from its Moldovan counterpart, with its own legislation and regulatory agency. Very few private media independent from the dominating Sheriff Corporation face huge obstacles, particularly in terms of the access to information and full freedom of operation including the attempts of censorship of information and influencing journalists. Such activities are characteristic for the quasi-authoritarian or authoritarian systems.

The future of the Moldavian media system is strictly connected with the development of democracy which seems to be in the state of constant transformation rather than the systemic consolidation. The domination of the media by political and business groups leads to the disappearance of the control function of mass media and cramming them into the fights using propaganda narration.

\begin{abstract}
The article presents the main problems of the Moldovan media system which are mainly connected with the level of development of the political system. It is difficult to assume it as the stable one, especially in the context of problems associated with the election of the president or methods of election of the head of the state challenged by the Constitutional Court. Another problem is a strong politicizing of public institutions which makes it possible to use them in the political fight. The ongoing process of oligarchization of economy also finds it reflection on the media market. The influential businesspeople of the Moldovan economy are connected with concrete political groups. These sympathies manifest in the selectivity of the broadcast and presented program content and favoring of specific political options competing on the Moldovan political scene. The future of the media system is strictly associated with the development of Moldovan democracy, which seems to be in the constant process of transformation rather than systemic consolidation. The domination of the media system by political and business groups leads to the disappearance of the control function of the mass media and cramming them into duels using propaganda narration.
\end{abstract}

Key words: Moldovan media system, mass media.

48 M. Sirkeli, op. cit., p. 113. 


\section{System medialny Republiki Mołdawii}

Streszczenie: W artykule zaprezentowano główne problemy mołdawskiego systemu medialnego, które mają związek przede wszystkim z poziomem rozwoju systemu politycznego. Trudno uznać go za stabilny, zwłaszcza w kontekście problemów dotyczących wyboru prezydenta lub też zakwestionowania przez Sąd Konstytucyjny metody elekcji głowy państwa. Innym problemem jest silne upolitycznienie instytucji publicznych, które pozwala wykorzystywać je w walce politycznej. Postępujący proces oligarchizacji gospodarki ma swoje odzwierciedlenie także na rynku medialnym. Dominujący w mołdawskiej gospodarce biznesmeni są natomiast powiązani z konkretnymi grupami politycznymi. Sympatie owe przejawiają się przede wszystkim w selektywności w doborze emitowanych i prezentowanych treści programowych oraz faworyzowaniu określonych opcji politycznych rywalizujących na mołdawskiej scenie politycznej. Przyszłość mołdawskiego systemu medialnego jest ściśle związana z rozwojem mołdawskiej demokracji, która wydaje się być permanentnie w stanie transformacji, a nie konsolidacji systemowej. Zdominowanie mediów przez grupy polityczno-biznesowe prowadzi zaś do zaniku kontrolnej funkcji środków masowego przekazu i wtłoczenia ich w pojedynki na narracje propagandowe.

Słowa kluczowe: system medialny Mołdawii, media, środki masowego przekazu

\section{Медиасистема Республики Молдова}

Аннотация: В статье представлены основные проблемы молдавской медиасистемы, которые прежде всего связаны с уровнем развития политической системы. Её сложно считать стабильной, особенно в контексте проблем, касающихся выбора президента или поставленного под сомнение Конституционным Судом способа избрания главы государства. Другой проблемой является сильная политизация публичных институтов, что позволяет использовать их в политической борьбе. Продолжающийся процесс олигархизации экономики отражается также на медиарынке. Однако бизнесмены, доминирующие в молдавской экономике, связаны с определенными политическими группами. Эти симпатии проявляются, прежде всего, в избирательности при выборе транслируемого и представляемого программного контента, а также в предоставлении преимущества определенным политическим сторонам, конкурирующим на политический арене Молдовы. Будущее молдавской медиасистемы тесно связано с развитием молдавской демократии, которая, по-видимому, постоянно находится в состоянии трансформации, а не системной консолидации. Доминирование политических и деловых групп над Сми приводит к исчезновению контрольной функции средств массовой информации и превращению их в поединки на пропагандистские нарративы.

Ключевые слова: медиасистема Молдовы, медиа, СМИ 


\section{Bibliography}

\section{Normative acts}

Constituția 29 iulie 1994, Monitorul Oficial al R.Moldova no.1 din 12.08.1994.

Lege Codul penal al Republicii Moldova nr. 985-XV din 18.04.2002 Republicat: Monitorul Oficial al R.Moldova nr.72-74/195 din 14.04.2009 Monitorul Oficial al R.Moldova no.128-129/1012 din 13.09.2002.

Lege Codul audiovizualului al Republicii Moldova nr. 260-XVI din 27.07.2006 Monitorul Oficial no.131133/679 din 18.08.2006.

Lege cu privire la libertatea de exprimare nr. 64 din 23.04.2010 Monitorul Oficial no.117-118/355 din 09.07.2010.

\section{Monographs and articles}

Całus K., Państwo niedokończone. 25 lat mołdawskiej niepodległości, Warszawa 2016.

Całus K., Mołdawia: Sąd Konstytucyjny zmienia tryb wyboru prezydenta, https://www.osw.waw.pl/pl/ publikacje/analizy/2016-03-09/moldawia-sad-konstytucyjny-zmienia-tryb-wyboru-prezydenta, 09.03.2016.

Media landscapes of Eastern Partnership countries, Yerevan Press Club, Yerevan 2011

Media sustainability index 2016, IREX, Waszyngton, 2016.

Oazu Nantoi, Vasile Cantarji, Igor Botan, Anatol Gremalschi, Mihail Sirkeli, Moldova between East and West: views from Gagauzia and Taraclia, Chisinau 2002.

Olchowik R., W 2016 r. startuje NTV Mołdawia, http://satkurier.pl/news/122954/w-2016r-startuje-ntv-moldawia.html.

Oniszczuk Z., Gierula M.,_Mało znane systemy medialne, Sosnowiec 2007.

Press Freedom Report, Independent Journalism Center, Chisinau 2015.

Puju A., Media masowe w przestrzeni społeczno-politycznej współczesnej Mołdowy [in:] Mało znane systemy medialne, Sosnowiec 2007.

Rajczyk R., System konstytucyjny Mołdawii, Warszawa 2012.

Raport privind activitatea CCC in anul 2015, http://www.cca.md/files/RAPORT\%20CCA\%202015.pdf

Sirkeli M., The ATU Gagauzia informational space and its influence on the moods of the public in the region, [in:] Oazu Nantoi, Vasile Cantarji, Igor Botan, Anatol Gremalschi, Mihail Sirkeli, Moldova between East and West: views from Gagauzia and Taraclia, Chisinau 2002

Zdaniuk B., Konsolidacja państwa w Republice Mołdawii, Warszawa 2016.

Обзор телевизионной аудитории за декабрь 2016 года, TV MR MLD December 2016.

\section{Internet sources}

http://media-azi.md/

http://www.statistica.md

http://www.internetlivestats.com/internet-users/moldova/

http://www.cca.md

http://www.agb.md 
Pobrane z czasopisma Wschód Europy http://journals.umcs.pl/we

Data: 26/04/2023 16:20:11

http://www.top20.md/stiri-massmedia

http://www.aapm.md/rom.htm

http://www.newsmoldova.md/

https://novostipmr.com/en

http://r-novosti.idknet.com/

http://tiraspol.tripod.com/

http://vestipmr.info

https://www.rise.md

http://bendery-ga.org

http://www.ipp.md 